Research Article

\title{
The Existence of Fourier Coefficients and Periodic Multiplicity Based on Initial Values and One-Dimensional Wave Limits Requirements
}

\author{
Adi Jufriansah 1,a,", Azmi Khusnani ${ }^{1, b}$, Arief Hermanto ${ }^{2, c}$, Mohammad. Toifur ${ }^{3, d}$, \\ and Erwin Prasetyo ${ }^{1,4, e}$
}

\author{
${ }^{1}$ Department of Physics Education, Faculty of Mathematics and Science Education, IKIP Muhammadiyah Maumere \\ Jenderal Sudirman Street, Maumere 86118, Indonesia \\ ${ }^{2}$ Department of Physics, Faculty of Mathematics and Natural Sciences, Universitas Gadjah Mada \\ Sains Street, Special Region of Yogyakarta 55281, Indonesia \\ ${ }^{3}$ Department of Magister Physics Education, Graduate Program, Universitas Ahmad Dahlan \\ Pramuka Street, Special Region of Yogyakarta 55161, Indonesia \\ ${ }^{4}$ Department of Science Education, Doctoral Program, Graduate Program, Universitas Negeri Surabaya \\ Ketintang Street, Surabaya 60231, Indonesia
e-mail: $\underline{\text { a saompu @gmail.com, }}{ }^{\mathrm{b}}$ husnaniazmi@gmail.com, ${ }^{\mathrm{c}}$ arief hermanto@ugm.ac.id, ${ }^{\mathrm{d}}$ mtoifur@yahoo.com, and ${ }^{\mathrm{e}}$ wintyo212@gmail.com
* Corresponding Author

\begin{abstract}
Physical systems in partial differential equations can be interpreted in a visual form using a wave simulation. In particular, the interpretation of the differential equations used is in the nonlinear hyperbolic model, but in its completion, there are some limitations to the stability requirements found. The aim of this study is to investigate the analytical and numerical analysis of a wave equation with a similar unit and fractal intervals using the Fourier coefficient. The method in this research is to use the analytical solution approach, the spectral method, and the finite difference method. The hyperbolic wave equation's analytical solution approach, illustrated in the Fourier analysis, uses a pulse triangle. The spectral method minimizes errors when there is the addition of the same sample grid points or the periodic domain's expansion with a trigonometric basis. Meanwhile, different ways offer a more efficient solution. Based on the research results, the information obtained is that the Fourier analysis illustrates the pulse triangle use to solve the solution. These results are also suitable for adding sample points to the same spectra. Fourier analysis requires a relatively long time to solve one pulse triangle graph to need another solution, namely the finite difference method. However, its use is still limited in terms of stability when faced with more complex problems.
\end{abstract}

Keywords: Partial Differential Equations; Fourier Analysis; Finite Difference; Wave Equation

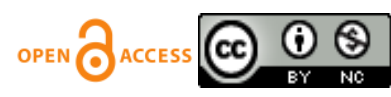




\title{
Eksistensi Koefisien Fourier dan Multiplisitas Berkala Berdasarkan Nilai Awal dan Syarat Batas Gelombang Dimensi Satu
}

\begin{abstract}
Abstrak
Sistem fisis pada persamaan diferensial parsial dapat diinterpretasi dalam bentuk visual dengan menggunakan simulasi gelombang. Secara khusus, interpretasi dari persamaan diferensial yang digunakan adalah dalam model hiperbolik nonlinier, namun dalam penyelesainnya, ditemukan beberapa keterbatasan syarat kestabilan. Tujuan dari penelitian ini adalah untuk menyelidiki analisis analitik dan numerik dari suatu persamaan gelombang dengan interval satuan dan fraktal yang serupa menggunakan koefisien fourier. Metode pada penelitian ialah menggunakan pendekatan solusi analitik, metode spektral dan metode beda hingga. Pendekatan solusi analitik persamaan gelombang hiperbolik yang dilustrasi kedalam analisis fourier menggunakan segitiga pulsa. Metode spektral dengan minimalisasi kesalahan ketika ada penambahan titik grid sampel yang sama atau penambahan domain periodik dengan basis trigonometri. Sedangkan pada metode beda hingga sebagai tawaran solusi penyelesaian yang lebih efisien. Berdasarkan hasil penelitian, menunjukkan bahwa keberadaan analisis fourier dengan ilustrasi segitiga pulsa dapat dijadikan sebagai solusi penyelesaian. Hal ini diperkuat kesesuaian hasil yang diperoleh ketika ada penambahan titik sampel dalam spektral yang sama. Analisis fourier membutuhkan waktu yang relatif lama untuk memecahkan satu grafik segitiga pulsa sehingga membutuhkan solusi lain yaitu metode beda hingga, walaupun dalam penggunaannya masih terbatas dalam hal stabilitas jika dihadapkan pada masalah yang lebih kompleks.
\end{abstract}

Kata Kunci: Persamaan Diferensial Parsial; Analisis Fourier; Beda Hingga; Persamaan Gelombang

PACS: 02.30.Jr; 02.30.Nw; 02.70.Bf; 03.65.Ge

(C) 2020 Jurnal Penelitian Fisika dan Aplikasinya (JPFA).This work is licensed under CC BY-NC 4.0

Article History: Received: February 7, 2020

Accepted: December 2, 2020
Aproved with minor revision: December 24, 2020

Published: December 31, 2020

Howtocite: Jufriansah A, et al. The Existence of Fourier Coefficients and Periodic Multiplicity Based on Initial Values and One-Dimensional Wave Limits Requirements. Jurnal Penelitian Fisika dan Aplikasinya (JPFA). 2020; 10(2): 146-157. DOI: https://doi.org/10.26740/jpfa.v10n2.p146-157.

\section{INTRODUCTION}

A partial differential equation (PDE) is a form of equation found in many physics applications, such as suspension bridges [1,2]. Hanging bridge modeling in physical concept is closely related to waves in physics [3]. The importance of using PDE is to build a model mathematically, making it easier to study the physical system of a model in physics applications [4].

The physical system for partial differential equations can be interpreted in visual form using wave simulation [3-8]. The interpretation of differential equations used is a nonlinear hyperbolic model $[9,10]$. An example of a phenomenon that applies this model is mechanical wave propagation $[1,2,11]$, and the solution for this model uses the finite difference method [12]. However, in its completion, several limitations of stability requirements were found. Although this problem is not directly related to the classical wave problem, it is related to a Fourier analysis review [13-15].

In general, the mechanical wave propagation equation has a complicated solution. This is because the equation is nonlinear [16-19]. Several other studies [20-24] also stated that this phenomenon is diverse, so that it has many possibilities in its 
resolution. Based on these characteristics, the solutions offered also vary. One of the methods provided in solving is by utilizing Fourier analysis.

Blomker [25] states that a solution using Fourier can be used as a predictor to generalize the waves discussed. However, Gourevitch [26] said that the use of the new Fourier is limited to determining the Fourier coefficient at certain intervals only by integration. Relatively long and complex integrations often result in relatively simple formulas for the Fourier coefficients and $b_{n}$ [24]. This raises the question of whether to obtain the Fourier coefficient at any point. This is only determined by the extraordinary coefficient to determine the Fourier coefficient in the case of one-dimensional waves.

This study focuses more on propagating the pulse triangle as an illustration of the Fourier coefficient's existence with the addition of the periodic domain mechanism so that the solution used is the analytic iteration model or the $n$ step. As mentioned, this study aims to examine the analytic and numerical analysis of wave equations with similar fractal and interval units.

\section{METHOD}

\section{Hyperbolic Wave Equation Analytic Solution}

Analytical solution of wave equations can be solved by using the Laplacian approach [27], wherewith this approach a one-dimensional wave equation can be defined as Equation (1).

$$
\nabla^{2} u=\frac{1}{c^{2}} \frac{\partial^{2} u}{\partial t^{2}}
$$

In mechanical waves, a one-dimensional wave can be illustrated by a wave vibrating against the periodic axis so that the net force on the horizontal axis is zero, which results in the resultant force being

$$
\sum F_{y}=T_{(x+\Delta x)} \sin \theta_{2}-T_{x} \sin \theta_{1}
$$

with value $\tan \theta_{1}=\left.\frac{\partial u}{\partial x}\right|_{x} \tan \theta_{2}=\left.\frac{\partial u}{\partial x}\right|_{(x+\Delta x)}$ and the amount of force obtained is

$$
\sum F_{y}=T\left(\left.\frac{\partial u}{\partial x}\right|_{(x+\Delta x)}-\left.\frac{\partial u}{\partial x}\right|_{x}\right)
$$

Based on Newton's second law, it is obtained,

$$
\mu \frac{\partial^{2} u}{\partial t^{2}}=T \frac{\left(\left.\frac{\partial u}{\partial x}\right|_{(x+\Delta x)}-\left.\frac{\partial u}{\partial x}\right|_{x}\right)}{\Delta x}
$$

and to illustrate Fourier's analysis based on Equation (4), it can be modeled in Figure 1.

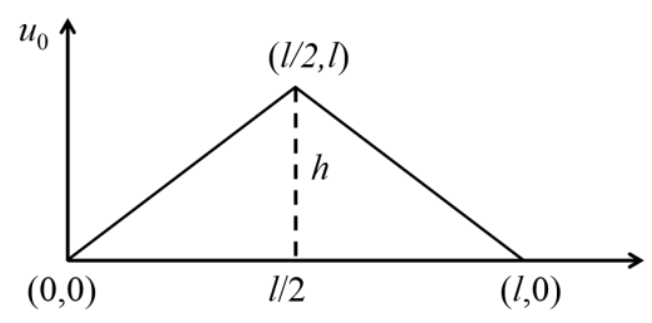

Figure 1. Pulse Triangle at $t=0 \mathrm{~s}$ where $t$ is $0, u_{0}$ is

$$
u_{0}\left\{\begin{array}{l}
\frac{2 h x}{l} ; 0<x<\frac{l}{2} \\
\frac{2 h}{l}(x-l) ; \frac{l}{2}<x<l
\end{array}\right.
$$

\section{Spectral Method}

The calculation of the convergence of the solution using more grid points is used to estimate the derivative of a function. One of the methods used is the periodic method, which is known to be accurate, where $\mathrm{n}$ is the order of the point size of the grid for each sample [28]. The goal is to formulate the periodic domain using trigonometric bases with equal distances. As the sample size increases, the error should decrease so that solutions can be distinguished. If solved by the Fourier approach, this will be 


$$
\frac{d^{k} U_{N}}{d x^{k}}\left(x_{j}\right)=\sum_{|n| \leq N}(i n)^{k} b_{n} e^{i[2 \pi i] n\left(x_{j}\right)}
$$

where $k$ is the order of the derivative, $n$ is the Fourier mode, $l$ is the length of the spatial domain, and $b_{n}$ is the Fourier coefficient.

The solution chosen uses the interpolation function so that

$$
U_{N}(x)=\sum_{n=0}^{N} b_{n} \varphi_{n}(x)
$$

with $\quad b_{n}=\frac{1}{N} \sum_{j=0}^{N-1} U\left(x_{j}\right) e^{i n x_{j}}$

If approximated by the square of the Fourier mode sequence, the second-order spatial derivative can be formulated

$$
U_{x x}=-n^{2} \hat{a}_{n}
$$

The order of the Fourier modes is arranged to be evenly uniform across the spatial grid with

$$
n=1 i\left[\left(-\frac{N}{2}+1\right), 0,\left(\frac{N}{2}-1\right)\right]
$$

When applied to a hyperbolic wave, the spatial Fourier transform on both sides is obtained

$$
\begin{aligned}
& \nabla^{2} u=\frac{1}{c^{2}} \frac{\partial^{2} u}{\partial t^{2}} \\
& \int_{-\infty}^{\infty}\left[\frac{\partial^{2} u}{\partial x^{2}}\right] e^{-\beta x} d x=\int_{-\infty}^{\infty}\left[\frac{\partial^{2} u}{\partial t^{2}}\right] e^{-\beta x} d x
\end{aligned}
$$

\section{Finite Difference Method (FDM)}

Classical numerical techniques can be used to estimate some solutions to the problem of the initial equation of the wave value written as a function with the amplitude $u(x, t)$, which states that $x$ is a function of position and $t$ as a function of time according to Equation (12) [29].

$$
c^{2} u_{x x}=u_{t t}
$$

with

$$
\begin{aligned}
& 0 \leq x \leq x_{f} \\
& 0 \leq t \leq T
\end{aligned}
$$

with a hyperbolic scheme, as shown in Figure 2.

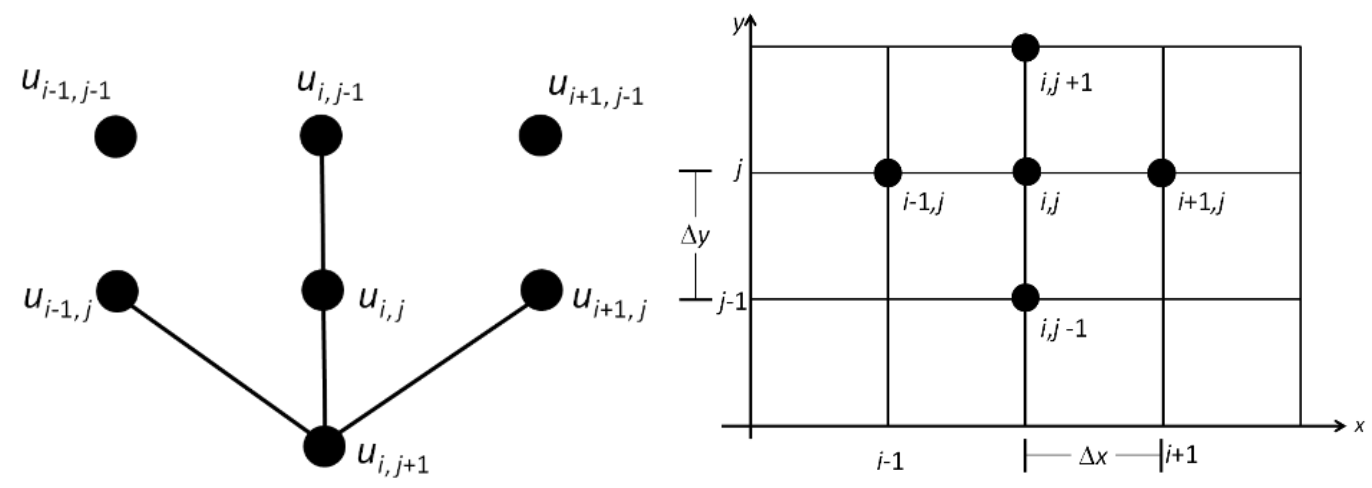

Figure 2. Hyperbolic Scheme

Figure 2 can be seen in [30,31]. To solve Equation (12), it must be accompanied by initial conditions and boundary conditions, initial conditions

$$
u(x, 0)=i_{0}(x), \frac{\partial u}{\partial t}(x, 0)=i 1_{0}(x)
$$

and boundary conditions

$$
u(0, t)=b_{0}(t), u\left(x_{f}, t\right)=b_{x_{f}}(t)
$$

\section{III.RESULTS AND DISCUSSION}

One dimensional wave can be solved by assuming $u(x, t)=X(x) T(t)$, this solution is used to explain the behavior of the system presented in Equation (1) [32,33]. Based on Equation (1), it is known that the right and left side segments only have $t$ as a function of time and $x$ as a function of distance. So, to solve the two systems, an example is carried out with a 
certain constant $\left(-k^{2}\right)$ for each segment, where $k$ is the number of waves.

$$
\begin{aligned}
& \frac{d^{2} T}{d t^{2}}+k^{2} c^{2} T=0 \\
& \frac{d^{2} X}{d x^{2}}+k^{2} X=0
\end{aligned}
$$

Equation (16) produces the characteristic equation [30], for the right-hand side system is

$$
D_{1,2}= \pm k c i
$$

while on the left side, Equation (17) yields

$$
D_{1,2}= \pm k i
$$

So that Equation (16) produces a solution,

$$
T(t)=A_{1} \sin k c t+A_{2} \cos k c t
$$

If $A_{1}$ and $A_{2}$ are constants determined by the initial condition $d T / d t(0)=0$, then it is obtained,

$$
T(t)=A_{1} \cos k c t
$$

while Equation (17) produces a solution,

$$
X(x)=B_{1} \sin k x+B_{2} \cos k x
$$

If $B_{1}$ and $B_{2}$ are constants that are determined by the boundary conditions $X(0)=0$, then $B_{2}=0$ is obtained,

$$
X(x)=B_{1} \sin k x
$$

To obtain the complete solution as follows,

$$
\begin{aligned}
u(x, t) & =X(x) T(t) \\
& =A_{1} B_{1} \sin k x \cos k c t
\end{aligned}
$$

$A_{1}$ and $B_{1}$ are constants, so they can be written as a new constant $C$, so Equation (24) can be written,

$$
u(x, t)=C \sin k x \cos k c t
$$

The boundary conditions of Equation (20) and Equation (22) apply to the condition $u=(0, t)=u(l, t)=0$ and have an initial condition in idle state $d u / d t(0)=0[34,35]$ so that,

$$
k=\frac{n \pi}{l}
$$

Giving initial conditions and boundary conditions causes Equation (25) to be

$$
u(x, t)=C \sin \frac{n \pi}{l} x \cos \frac{n \pi c}{l} t
$$

So $u_{0}$ is obtained

$$
u_{0}=C \sin \frac{n \pi}{l} x
$$

If continued using the Fourier series [36], it is obtained

$$
u_{0}=\sum b_{n} \sin \frac{n \pi}{l} x
$$

where $b_{n}$ is an odd function shown in Equation (30)

$$
b_{n}=\frac{2}{l}\left\{\begin{array}{c}
\int_{0}^{\frac{l}{2}} \frac{2 h}{l} x \sin \frac{n \pi x}{l} d x+ \\
\int_{\frac{l}{2}}^{l}-\frac{2 h}{l}(x-l) \sin \frac{n \pi x}{l} d x
\end{array}\right\}
$$

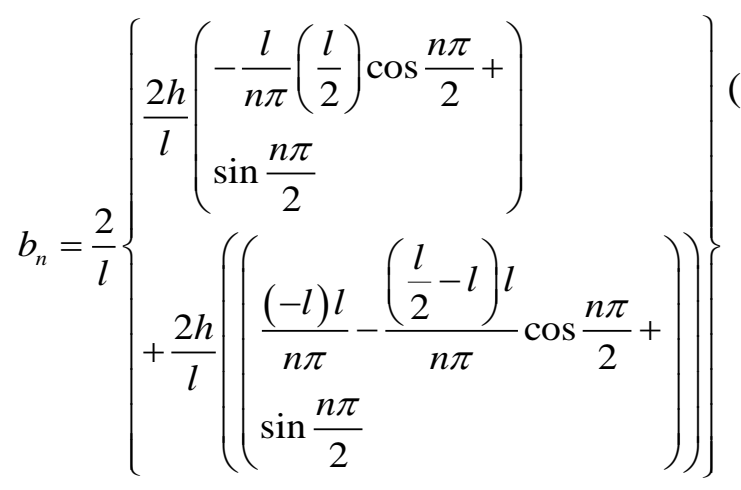

was obtained,

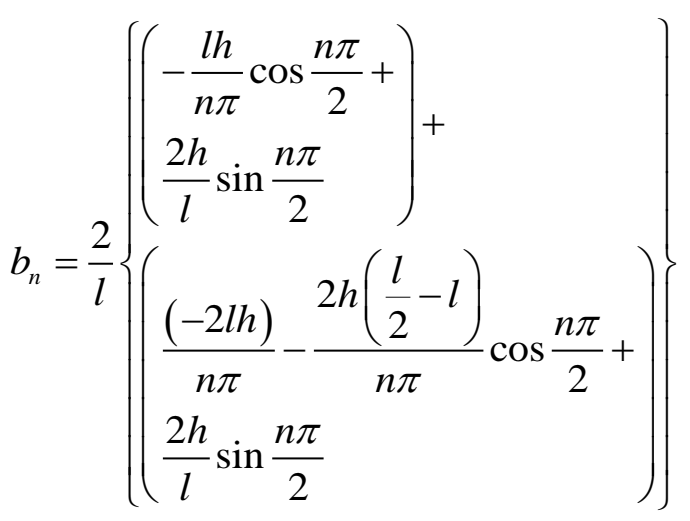


Equation (31) can be simplified into

$$
b_{n}=\frac{8 h}{l^{2}} \sin \frac{n \pi}{2}-\frac{4 h}{n \pi}
$$

If substituted, the value of $n=1,2,3, \ldots$ is obtained

$$
\begin{aligned}
& b_{1}=\frac{8 h}{l^{2}}-\frac{4 h}{\pi} \\
& b_{2}=-\frac{4 h}{2 \pi} \\
& b_{3}=-\frac{8 h}{l^{2}}-\frac{4 h}{3 \pi} \\
& b_{4}=-\frac{h}{\pi} \\
& b_{n}=\frac{8 h}{l^{2}} \sin \frac{n \pi}{2}-\frac{4 h}{n \pi}
\end{aligned}
$$

Then obtained,

$$
\begin{aligned}
u_{0}= & \left(\frac{8 h}{l^{2}}-\frac{4 h}{\pi}\right) \sin \frac{n \pi}{l} x- \\
& \frac{4 h}{2 \pi} \sin \frac{n \pi}{l} x- \\
& \left(\frac{8 h}{l^{2}}+\frac{4 h}{3 \pi}\right) \sin \frac{n \pi}{l} x- \\
& \frac{h}{\pi} \sin \frac{n \pi}{l} x+\cdots \\
u_{0}= & \sum_{n=1}^{n=\infty}\left(\frac{8 h}{l^{2}} \sin \frac{n \pi}{2}-\right) \sin \frac{n \pi}{l} x
\end{aligned}
$$

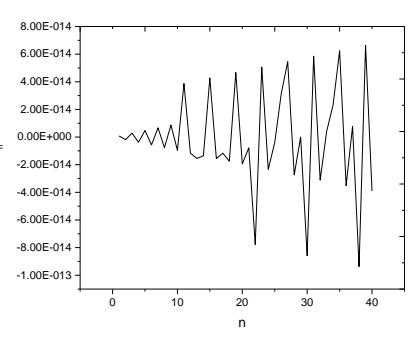

$n=1$

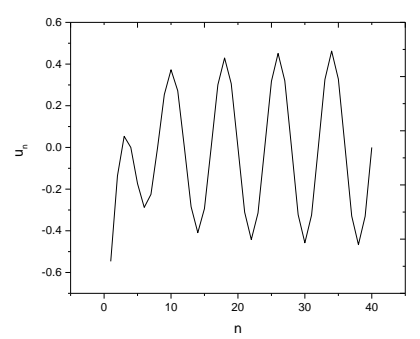

$n=4$

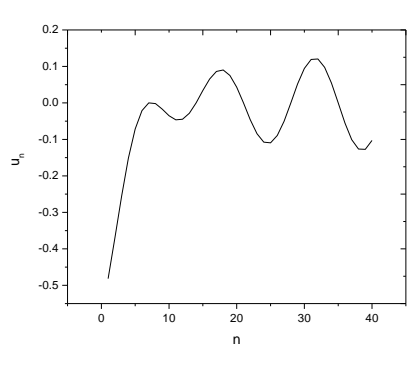

$n=7$

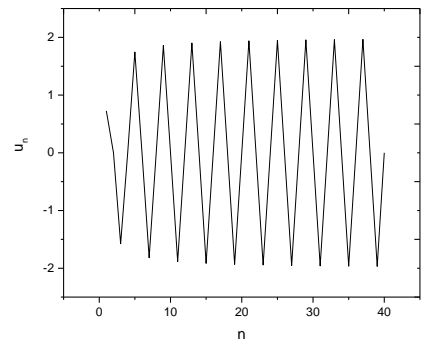

$n=2$

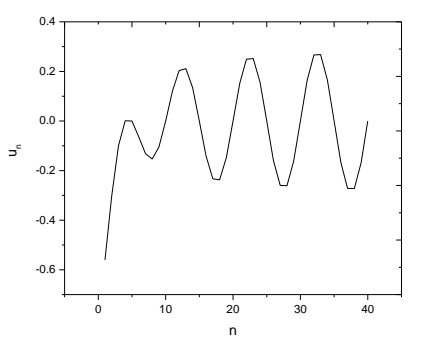

$n=5$

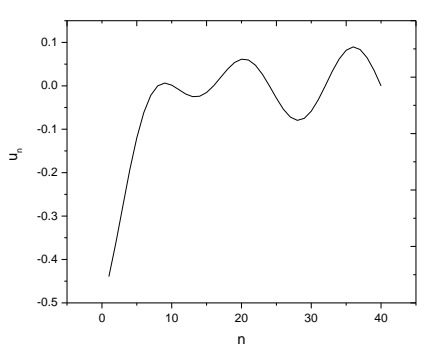

$n=8$

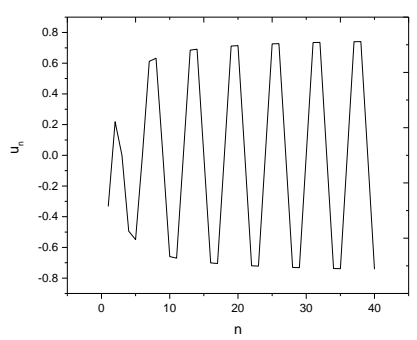

$n=3$

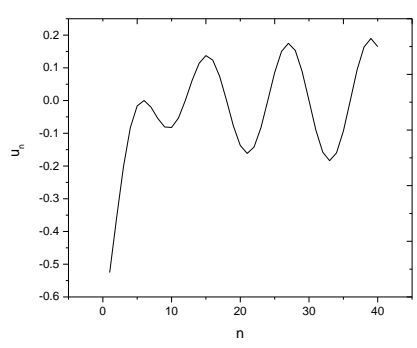

$n=6$

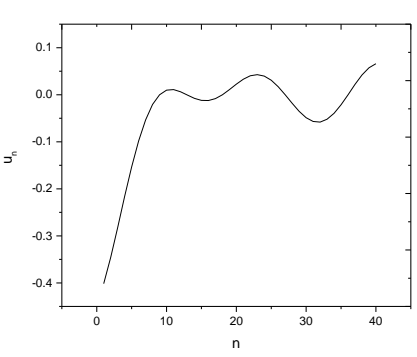

$n=9$

Figure 3. Fourier Coefficients Based on Equation (34) 
The results of the equation graph (34) are shown in Figure 3, while Equation (12) is solved by the formula [36-38],

$$
\begin{aligned}
& \frac{u_{t+1}^{k}-2 u_{t}^{k}+u_{t-1}^{k}}{\Delta x^{2}}=\frac{1}{c^{2}} \frac{u_{t}^{k+1}-2 u_{t}^{k}+u_{t}^{k-1}}{\Delta t^{2}} \\
& \Delta x=\frac{x_{f}}{m_{x}}, \Delta t=\frac{T}{n}
\end{aligned}
$$

where $x_{f}$ is the final boundary condition, $m_{x}$ is the number of parts of the $x$-axis, $T$ is the end time iteration, and $n$ is the number of time parts $t$.

The results of the translation of Equation (35) are obtained as follows,

$$
\begin{aligned}
& u_{t}^{k+1}=r\left(u_{t+1}^{k}+u_{t-1}^{k}\right)+2(1-r) u_{t}^{k}-u_{t}^{k-1} \\
& r=c^{2} \frac{\Delta t^{2}}{\Delta x^{2}}
\end{aligned}
$$

Because $u_{t}^{-1}=u\left(x_{t}-\Delta t\right)$ will not be obtained when $k=0$, then the initial condition forecast through the formula Equation (37) for order-1 as follows,

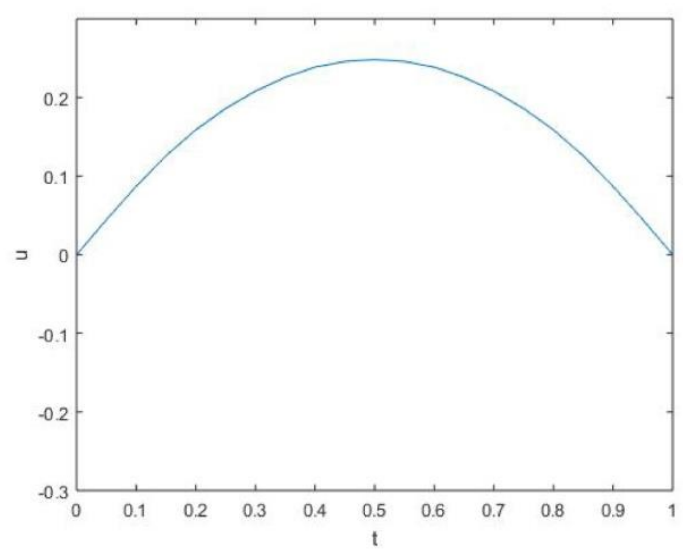

$$
\frac{u_{t}^{1}-u_{t}^{-1}}{2 \Delta t}=i_{0}^{\prime}\left(x_{t}\right)
$$

Equation (37) causes $u_{t}^{-1}=u_{t}^{1}-2 i_{0}^{\prime}\left(x_{t}\right) \Delta t$ thus for $k=0$ to be obtained,

$$
\begin{aligned}
u_{t}^{1}= & r\left(u_{t+1}^{0}+u_{t-1}^{0}\right)+2(1-r) u_{t}^{0}- \\
& \left(u_{t}^{1}-2 i_{0}^{\prime}\left(x_{t}\right) \Delta t\right) \\
u_{t}^{1}= & \frac{1}{2} r\left(u_{t+1}^{0}+u_{t-1}^{0}\right)+(1-r) u_{t}^{0}+ \\
& i_{0}^{\prime}\left(x_{t}\right) \Delta t
\end{aligned}
$$

The values for $k$ are 1, 2, 3,.. which can easily be obtained from the previous iteration equation. If the stability value can be guaranteed with accuracy, then the approximate fix solution according to Gerd [39] is the value of $r \leq 1$, or reduced so that the iteration results are shown in Figures 4 and Figure 5.

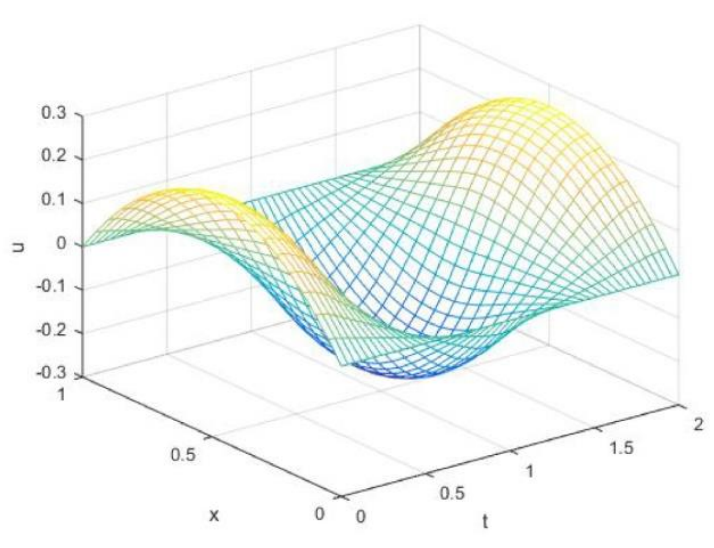

Figure 4. One-Dimensional Wave Equation for $t=1 \mathrm{~s}$

When compared to other methods, this method is relatively simple [40]. Then confirmed by $[32,33]$ who need Cauchy's data to describe the expansion of the wave equation.

Figure 4 is obtained based on equation (1) when $t=1 \mathrm{~s}$, with the parameter wave velocity $c$ of $1 \mathrm{~m} / \mathrm{s}, x_{f}=1 \mathrm{~m}, m_{x}=20, T=2 \mathrm{~s}$, $n=50 \mathrm{~s}$, at $0 \leq t \leq 2 \quad \mathrm{~s}$ and the boundary condition $0 \leq x \leq 1 \mathrm{~m}$. To see the whole wave, it is necessary to increase the time interval $0 \leq t \leq 15 \mathrm{~s}$ and the boundary condition $0 \leq x \leq 4$ $\mathrm{m}$ so that Figure 5 can be obtained. If further extrapolation is carried out in equation (38), a visualization of a wave that is moving sloping will be obtained, which is the same 
as the results of Fourier equation (34) and as shown in Figure 5. This is also in line with research conducted by Jufriansah et al [41] and Peng et al [42].

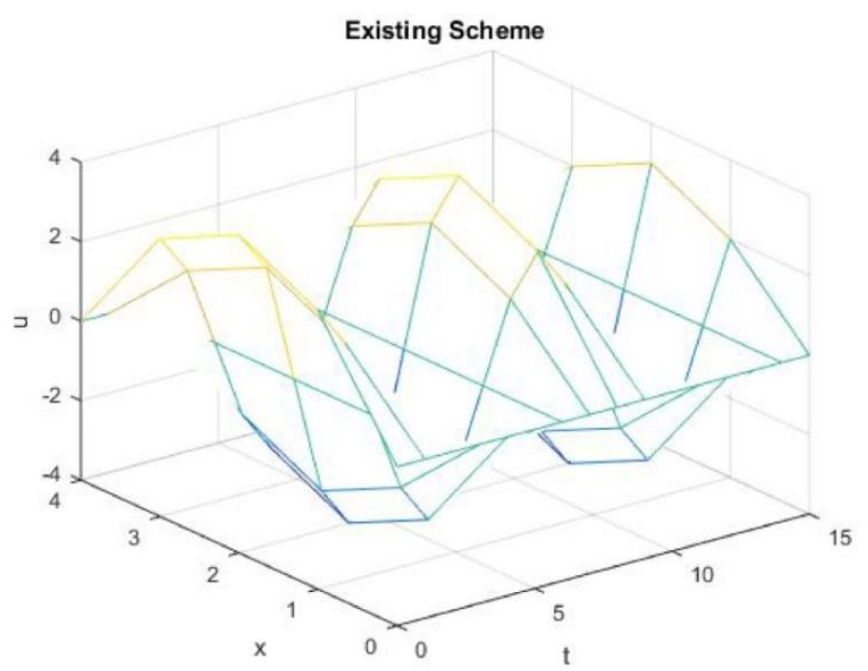

Figure 5. Equity Wave Dimension One for $t=15 \mathrm{~s}$

The analysis results noted that that 1-dimensional waves could be solved using the Fourier approach in terms of the systematic multiplicity method and finite difference methods at similar fractals.

However, if applied to an irregular function domain such as the multidimensional case or a conservative problem such as weakly damped waves, see [6], it requires a different method.

The constraints in the Fourier method are limited to hyperbolic equations. In contrast, FDM is limited to the initial conditions and limitations given. If given outside this equation, FDM cannot maintain system stability. The advantage of using Fourier is that it does not require iteration, but Fourier's disadvantage is that it takes a relatively long time to complete one wave. In FDM, the advantage is that it is easy and efficient to solve the wave equation, but the disadvantage is that it does not apply to unstructured functions $u(x, t)$.

This research can be applied to relevant research studies such as mechanical wave propagation based on the research results. This study also provides an opportunity to develop different fractal case methods to answer other processes' efficiency.

\section{CONCLUSION}

The periodic function using the Fourier series is more complicated than previously thought. The simplest interpretation of the Fourier series is a singularity isolated from the function at a particular point, which might differ at another point. If the mesh point is extended to $n$ iterations, it will take a long time to solve the problem. In the same fractal problem, there is a Fourier series conformity and an explicit finite difference pattern. So that the explicit pattern that occurs in the Fourier series can be approached using finite difference and simpler methods. The finite difference method can be used as a predictor no matter how much iteration is carried out, even though its use is still limited in terms of stability when faced with more complex problems such as dissimilar fractal problems.

\section{ACKNOWLEDGMENT}

The researcher expressed his gratitude to Lembaga Penelitian Pengembangan dan Pengabdian Masyarakat (LP3M) IKIP 
Muhammadiyah Maumere for research funding with OBE (Outcome Based Education) scheme.

\section{REFERENCES}

[1] Ohene KR, Osei - Frimpo E, Mends - Brew E, and King AT. A Mathematical Model of ASuspension Bridge - Case Study: Adomi Bridge, Atimpoku, Ghana. Global Advanced Research Journal of Engineering, Technology and Innovation. 2012; 1(3): 047-062. Available from: http://beta.garj.org/garjeti/abstract/2012/Jun e/Kwofie\%20et\%20al.htm.

[2] Berchio E, Ferrero A, and Gazzola F. Structural Instability of Nonlinear Plates Modelling Suspension Bridges: Mathematical Answers to Some Long-Standing Questions. Nonlinear Analysis: Real World Applications. 2016; 28: 91-125. DOI:

https://doi.org/10.1016/j.nonrwa.2015.09.00 5.

[3] Ming CY. Solution of Differential Equations with Applications to Engineering Problems. Dynamical Systems - Analytical and Computational Techniques; 2017: 233-264. DOI: http://dx.doi.org/10.5772/67539.

[4] Zhukovsky KV. A Method of Inverse Differential Operators Using Orthogonal Polynomials and Special Functions for Solving Some Types of Differential Equations and Physical Problems. Moscow University Physics Bulletin. 2015; 70: 93-100. DOI:

https://doi.org/10.3103/S0027134915020137.

[5] Feng L, Liu F, Turnerra I, Yang Q, and Zhuang P. Unstructured Mesh Finite Difference/Finite Element Method for The 2D Time-Space Riesz Fractial Diffusion Equation on Irregular Convex Domains Applied Mathematical Modelling. 2018; 59: 441-463. DOI:

https://doi.org/10.1016/j.apm.2018.01.044.
[6] Jufriansah A, Hermanto A, Toifur M, and Prasetyo E. Investigation of The Physics Phenomena of Weakly Damped Wave Equations with Forced Force: Theory and Simulation. Journal of Physics: Conference Series. 2020; 1567: 022012. DOI: https://doi.org/10.1088/1742-6596/1567/2/0 22012.

[7] Zhang W and Jiang J. A New Family of Fourth-Order Locally One-Dimensional Schemes for The Three-Dimensional Wave Equation. Journal of Computational and Applied Mathematics. 2017; 311: 130-147. DOI:

https://doi.org/10.1016/j.cam.2016.07.020.

[8] Zhang W. A New Family of Fourth-Order Locally One-Dimensional Schemes for The 3D Elastic Wave Equation. Journal of Computational and Applied Mathematics. 2019; 348: 246-260. DOI: https://doi.org/10.1016/j.cam.2018.08.056.

[9] Arioli G and Gazzola F. On a Nonlinear Nonlocal Hyperbolic System Modeling Suspension Bridges. Milan Journal of Mathematics. 2015; 83: 211-236. DOI: https://doi.org/10.1007/s00032-015-0239-9.

[10] Bennour A, Khodja FA, and Teniou D. Exact and Approximate Controllability of Coupled One-Dimensional Hyperbolic Equations. Evolution Equations and Control Theory. 2017; 6(4): 487-516. DOI: https://doi.org/10.3934/eect.2017025.

[11] Hui Y, Kang HJ, Law SS, and Hua XG. Effect of Cut-Off Order of Nonlinear Stiffness on The Dynamics of A Sectional Suspension Bridge Model. Engineering Structures. 2019; 185: 377-391. DOI: https://doi.org/10.1016/j.engstruct.2019.01.1 29.

[12] Fan N, Zhao LF, Xie XB, and Yao ZX. A Discontinuous-Grid Finite-Difference Scheme for Frequency-Domain 2D Scalar Wave Modeling. Geophysics. 2018; 83(4): T235-T244. DOI: https://doi.org/10.1190/geo2017-0535.1. 
[13] Strichartz RS. A Guide to Distribution Theory and Fourier Transforms. USA: World Scientific; 2003.

[14] Strichartz RS. Differential Equations on Fractals: A Tutorial. New Jersey: Princeton University Press; 2006.

[15] Shen J, Tang T, and Wang LL. Spectral Methods: Algorithms, Analysis and Applications. Springer Series in Computational Mathematics, Vol. 41. New York: Springer; 2011. DOI: http://dx.doi.org/10.1007/978-3-540-710417.

[16] Korkmaz A. Explicit Exact Solutions to Some One-Dimensional Conformable Time Fractional Equations. Waves in Random and Complex Media. 2019; 29(1): 124-137. DOI: https://doi.org/10.1080/17455030.2017.1416 702.

[17] Xie J, Xu X, Li A, and Zhu Q. Experimental Validation of Frequency-Domain Finite-Difference Model of Active Pipe-Embedded Building Envelope in Time Domain by Using Fourier Series Analysis. Energy and Buildings. 2015; 99: 177-188. DOI:

https://doi.org/10.1016/j.enbuild.2015.04.04 3.

[18] Don WS, Gao Z, Li P, and Wen X. Hybrid Compact-WENO Finite Difference Scheme with Conjugate Fourier Shock Detection Algorithm for Hyperbolic Conservation Laws. SIAM Journal on Scientific Computing. 2016; 38(2): A691-A711. DOI: https://doi.org/10.1137/15M1021520.

[19] Ji S. Periodic Solutions for One Dimensional Wave Equation with Bounded Nonlinearity. Journal of Differential Equations. 2018; 264(9): 5527-5540. DOI: https://doi.org/10.1016/j.jde.2018.02.001.

[20] Ji S, Gao Y, and Zhu W. Existence and Multiplicity of Periodic Solutions for Dirichlet-Neumann Boundary Value Problem of A Variable Coefficient Wave Equation. Advanced Nonlinear Studies. 2016;
16(4): 765-773. DOI:

https://doi.org/10.1515/ans-2015-5058.

[21] Chambers DH, Chandrasekaran $\mathrm{H}$, and Walston SE. Fourier Method for Calculating Fission Chain Neutron Multiplicity Distributions. Nuclear Science and Engineering. 2016; 184(2): 244-253. DOI: https://doi.org/10.13182/NSE15-109.

[22] Zhang TW and Han SF. Multiplicity of Almost Periodic Oscillations in Delayed Harvesting Predator-Prey Model with Modified Leslie-Gower Holling-Type II Schemes. ScienceAsia. 2019; 45(5): 494-501. DOI:

https://doi.org/10.2306/scienceasia1513-187 4.2019.45.494.

[23] Ambrosio V, Bartolo R, and Bisci GM. A Multiplicity Result for A Non-Local Parametric Problem with Periodic Boundary Conditions. Arkiv för Matematik. 2020; 58(1): 1-18. DOI:

https://dx.doi.org/10.4310/ARKIV.2020.v58. n1.a1.

[24] Kuznetsov DF. Expansion of Iterated Stratonovich Stochastic Integrals of Multiplicity 3 Based on Generalized Multiple Fourier Series Converging in The Mean: General Case of Series Summation. Preprint arXiv:1801.01564.2018; 2018. Available from:

https://arxiv.org/abs/1801.01564.

[25] Blömker D, Wacker $P$, and Wanner $T$. Probabilistic Estimates of the Maximum Norm of Random Neumann Fourier Series. Communications in Nonlinear Science and Numerical Simulation. 2017; 47: 348-369. DOI:

https://doi.org/10.1016/j.cnsns.2016.11.023.

[26] Gourevitch D, Gustafsson H, Kleinschmidt A, Persson D, and Sahi S. Fourier Coefficients and Small Automorphic Representations; 2018. Available from: http://hdl.handle.net/21.11116/0000-0002-82 B6-D. 
[27] Liu ZJ, Adamu MY, Enoch S, and Ji-Huan H. Hybridization of Homotopy Perturbation Method and Laplace Transformation for the Partial Differential Equations. Thermal Science. 2017; 21(4): 1843-1846. DOI: https://doi.org/10.2298/TSCI160715078L.

[28] Andrews U, Bonik G, Chen JP, Martin RW, and Teplyaev A. Wave Equation on One-Dimensional Fractals with Spectral Decimation and the Complex Dynamics of Polynomials. Journal of Fourier Analysis and Applications. 2017; 23: 994-1027. DOI: https://doi.org/10.1007/s00041-016-9494-6.

[29] Dobrokhotov SY and Nazaikinskii VE. Characteristics with Singularities and the Boundary Values of the Asymptotic Solution of the Cauchy Problem for A Degenerate Wave Equation. Mathematical Notes. 2016; 100: 695-713. DOI:

https://doi.org/10.1134/S0001434616110067.

[30] Bilbao S and Hamilton B. Higher-Order Accurate Two-Step Finite Difference Schemes for the Many-Dimensional Wave Equation. Journal of Computational Physics. 2018; 367: 134-165. DOI: https://doi.org/10.1016/j.jcp.2018.04.012.

[31] Murty AVSN, Srinivas MN, and Sastry DRVSRK. New Scheme for One Dimensional Wave Equation. International Journal of Civil Engineering and Technology (IJCIET). 2017; 8(8): 1028-1031. Available from:

http://www.iaeme.com/ijciet/IJCIET_Paper. asp?sno $=8807$.

[32] Szyszka B. A Nine-Point Finite Difference Scheme for One-Dimensional Wave Equation. AIP Conference Proceedings. 2017; 1863(1): 560078. DOI:

https://doi.org/10.1063/1.4992761.

[33] Agom EU, Ogunfiditimi FO, and Assi PN. Numerical Application of Adomian Decomposition Method to One Dimensional Wave Equations. Journal of Mathematical and Computational Science. 2017; 7(3): 554-563. Available from: http://scik.org/index.php/jmcs/article/view/3 036.

[34] Guo W and Guo BZ. Performance Output Tracking for A Wave Equation Subject to Unmatched General Boundary Harmonic Disturbance. Automatica. 2016; 68: 194-202. DOI:

https://doi.org/10.1016/j.automatica.2016.01 .041.

[35] Guo W, Zhou HC, and Krstic M. Adaptive Error Feedback Regulation Problem for 1D Wave Equation. International Journal of Robust and Nonlinear Control. 2018; 28(15): 4309-4329. DOI:

https://doi.org/10.1002/rnc.4234.

[36] Leukauf A, Schirrer A, and Talic E. Fourier Galerkin Approach to Wave Equation with Absorbing Boundary Conditions. World Academy of Science, Engineering and Technology. 2017; 11(8): 380-385. DOI: https://doi.org/10.5281/zenodo.1131844.

[37] Lissy P and Rovenţa I. Optimal Filtration for the Approximation of Boundary Controls for the One-Dimensional Wave Equation Using A Finite-Difference Method. Mathematics of Computation. 2019; 88: 273-291. DOI: https://doi.org/10.1090/mcom/3345.

[38] An Y. Uniform Dispersion Reduction Schemes for the One-Dimensional Wave Equation in Isotropic Media. Journal of Computational Physics. 2017; 341: 13-21. DOI:

https://doi.org/10.1016/j.jcp.2017.04.015.

[39] Gerdt VP, Robertz D, and Blinkov YA. Strong Consistency and Thomas Decomposition of Finite Difference Approximations to Systems of Partial Differential Equations. Preprint arXiv:2009.01731.2020; 2020. Available from: https://arxiv.org/abs/2009.01731.

[40] Taghizadeh N and Noori SRM. Reduced Differential Transform Method for Solving Parabolic-Like and Hyperbolic-Like Equations. SeMA Journal. 2017; 74(4): 559-567. DOI: 
https://doi.org/10.1007/s40324-016-0101-1. [41] Jufriansah A, Pramudya Y, Hermanto A, and Khusnani A. Surface Wave Topography using the 4 Point FDM Simulator. Science and Technology Indonesia. 2020; 5(4): 117-120. DOI:

https://doi.org/10.26554/sti.2020.5.4.117-120.
[42] Peng B, Luo CH, Sinha N, Tai CC, Xie X, and Xie H. Fourier Series Analysis for Novel Spatiotemporal Pulse Waves: Normal, Taut, and Slippery Pulse Images. Evidence-Based Complementary and Alternative Medicine. 2019; 2019: 5734018. DOI:

https://doi.org/10.1155/2019/5734018. 